\title{
TRAINING ON SWISHMAX APPLICATION TO IMPROVE ELEMENTARY SCHOOL TEACHERS' PROFESSIONAL COMPETENCES
}

\author{
Arvido Deca Verdian \\ Department of Primary Teacher \\ State University of Malang, Indonesia \\ arvidodeca3@gmail.com \\ Erine Anida Putri \\ Department of Primary Teacher \\ State University of Malang, Indonesia \\ erineanidaputri@gmail.com
}

\author{
Nanda Riski Septania \\ Department of Electrical Engineering \\ State University of Malang, Indonesia \\ nseptania@gmail.com \\ Yeni Purwaningtyas \\ Department of Primary Teacher \\ State University of Malang, Indonesia \\ yenipurwaningtyas@yahoo.com
}

\begin{abstract}
Along with technological advancement, it is expected that teachers can utilize it in learning process. Teachers are required to rule over many things in order to be able to manage the learning process becomes attractive, meaningful and fun, because the quality of the learning process is in the hands of teachers. With these demands, teachers must be able to utilize technology in the learning process. Besides it is easy and efficient, technology-based learning media are able to visualize various sciences so it will be easy to understand by the students. Flash application is a versatile application that can produce various learning media, such as games, slide presentations, and interactive videos. By learning about flash applications, the professional competence of teachers will increase because they have been able to take advantage of technology. Training about flash application is very necessary to introduce this utilization to elementary school teachers. The appropriate method used in this training is peer tutor (tutor sebaya) / TalkBound (getok tular) (TUSEGETUL). This method is done through 2 stages, namely preparation of tutor and dissemination. Tutor preparation is done with 2 techniques, namely training and workshop. While the dissemination is done by 2 techniques, namely training and science and technology mentoring.
\end{abstract}

Keywords: swishmax, flash application, elementary school, learning media

\section{INTRODUCTION}

Teachers nowadays are required to be a professional individual mastering several concerns. These abilities are related to teachers' role as facilitator and motivator who are able to design and present active, innovative, creative, effective, interesting, fun and technology-based learning. The use of learning media is necessary to help teachers to create their own learning media considering students' needs. Technology-based media is one solution. Besides it is simple and can be brought in the form of file, media creation can be adjusted looking at students' need. Yet, the creation of technology-based media should be accompanied by a fine ability of related programs or certain application. For about $60 \%$ of elementary school teachers in Ngunut sub-district have been able to operate computer. It means that the teachers are literate. Those teachers want to know deeper about how to take advantage of information and communication technology for learning.

Swishmax is a flash application which is easy to operate to produce a wide variety of leaning products, presentation slides, and interactive videos. Through this application, everyone can design a product which can be watched and understood by human. Since primary school students' thinking ability are still in the stage of operational-concrete, so teachers need to make abstract materials concrete to be easier to understand. By learning Swishmax application, elementary school teachers have their own chances to create their own learning media. By creating their own learning media, teachers do not need to worry about searching learning media in the Internet which may not be there or not suitable. Training and workshop on Swishmax application is a necessary activity to conduct to improve teachers' motivation and skills in creating technologybased learning media. Clusters of Kelompok Kerja Guru (KKG or teachers working group) can be used as a mean to share knowledge to all elementary school students in one sub-district. It is expected that this activity can enliven KKG's activity, especially in Ngunut sub-district, Tulungangung, East Java, Indonesia.

Swishmax is a program used to create animation of texts, images, and audios quickly and easily. Swishmax is completed with more than 230 effects. Moreover, Swishmax also has tools to make lines, squares, ovals, curves, motion paths, sprites, rollover buttons and input forms. Prior Swishmax development, Macromedia Flash software has been firstly famous among graphic designers. Yet, subsequent to this software launching, animators prefer use Swishmax to Macromedia Flash software since the use of animation script is easier and more effective. Compared to other software, Swishmax provides more button designs to ease animators to design. According to Fadhel (2012), "Swishmax is animation flash software which can be used to make presentation slides, animations, and websites, also can be used as additional media to edit video". In addition, Elka (nd) states that Swishmax is one of programs which can be used to make animation on texts, images, and audios quickly and easily.

Swishmax can be used as a tool to help learning process. Kurnia (2012) states, "the development of Swishmax as one of the media to deliver messages to children is an idea which can improve teachers' creativity in delivering materials to 
students". In fact, it still can be found teachers applying classical lecture method in delivering materials. On the other hand, learning materials can be delivered through technology-based media. By listening to lectures, every student will only imagine with different interpretation, because there is no clear visualization regarding teachers' explanation. The use of technology is very helpful for teachers to create appropriate learning media. Swishmax can be made as a combined tool of learning concepts and audiovisual technology producing new features which can be benefitted in education. Thus, multimedia-based learning can present learning materials which are more interesting, not monotonous, and ease students to learn certain materials independently through understanding they gain directly.

\section{TARGET}

\section{A. A General Illustration of Targeted People}

Ngunut sub-district is one of sub-districts which is quite developed enough in Tulungagung. The authority pays attention to the development of education. It is evident that 41 kindergarten, 45 primary schools, 7 junior high schools, and 4 senior high schools can be found in Ngunut whose area is 37.70 $\mathrm{km} 2$ in large consisting of 18 villages. Primary schools is first grade educational institution that has a pivotal role in building science and thinking connection and shaping students' characteristics, making it as a must to exist in every area. Based on the data in Ministry of Education and Culture (see http://referensi.data. kemendikbud.go.id/), the list of elementary schools is Ngunut is as follows: 11 schools in Ngunut village, 2 schools in Samir, 2 schools in Blaesono, 3 schools in Sumberejo Kulon, 2 schools in Gilang, 2 schools in Kalangan, 1 school in Kaliwungu, 2 schools in Pandansari, 5 schools in Pulosari, 1 school in Selorejo, 2 schools in Sumberejo Wetan, 2 schools in Sumberingin Kidul, 2 schools in Sumberingin Kulon, 2 schools in Kacangan, 1 school in Karangsono, 1 school in Kromasan, 2 schools in Purworejo, and 2 schools in Pulotondo. This number can meet the demand for basic education on elementary level throughout the village.

Primary schools teachers in Ngunut subdistrict are more than 270 people consisting of teacher for 1 st to 6 th grade and certain subjects. This number is divided into 8 unit of KKG which is disseminated based on the clusters or area. A cluster comprises of 5-6 schools in a certain area. KKG activities are centered in one certain main school. These formed clusters can work independently because the activities done more centrally under sub-district KKG, not actively by each KKG. To improve the quality of education, KKG needs to be optimally empowered. KKG is a tool for teachers to solve problems in teaching and learning activity, and get new information (Rasyid, 2015: 146). The problems range from challenges during learning, developing teaching materials, how to grab students' attention, and create an interesting, fun and meaningful learning nuance.

Learning media is the key point in awakening students learning motivation. Most of the teachers in Ngunut use their conventional way of teaching. In fact, in this global era, teachers need to be able to empower technology to create learning media. However, teachers in Ngunut sub-district only know Microsoft Office programs, especially Word and PowerPoint. Flash application as Swishmax is something new there. Thus, the existence of training on technological guidance is expected can help teachers to develop the process of teaching-learning activities to be more interactive and interesting so that the students are motivated to learn more diligently.

\section{B. Targeted Outcomes}

This training is expected can give significant progress towards primary schools teachers' competence. In terms of targeted outcomes, it can be divided into short- and long-term target. Projected short-term targeted outcomes are: First, is mproving professional competences of primary schools teachers in Ngunut sub-district; second, Developing skills of primary schools teachers in Ngunut sub-district in creating technology-based learning media; third, Enriching knowledge and skills of primary schools teachers in Ngunut sub-district in operating flash software; four, Creating learning media which can make abstract theories to be more concrete and easy to imagine; five, Improving motivation and skills of teachers in creating their own technology-based learning media. For the long-term outcomes, it is expected that this result of this study can be made of one of studied materials in KKG activities, to make a dynamic activity actively in KKG.

\section{Methods}

This program uses peer tutor and TalkBound as the methodology. Through peer tutor methodology, learning nuance becomes more relax so that teachers do not experience under pressure learning process. After teachers master this application through peer tutor, they have to teach this to other colleagues who have not mastered this application. That is why it is called as "getok tular" or TalkBound. This methodology is done through two stages. First stage is preparing tutors and the second is disseminating or transferring knowledge to colleagues. In the stage of preparing tutor, training and workshop are employed. Meanwhile in dissemination stage, training and accompaniment of science and technology are done. Plot and the explanation of each methodology are as follows:

\section{A. Prepare the Tutors}

This stage aims at preparing teachers who eventually will share their knowledge on their colleagues. Two techniques are implemented in this stage, as follows:

1. Training Techniques

Training is used to transfer the knowledge of Swishmax application and how to operate it from its experts. The studied materials are described below. From the basic knowledge they learned, teachers are expected to be able to understand and comprehend how to create simple and interesting learning media, and operate Swishmax to practice it directly. Training is done in 4 meetings (Table 1). 
Table 1

The Studied Materials in Training Swishmax Application

\begin{tabular}{|c|c|c|c|c|c|}
\hline No & Day, Date & Tools & Materials & Speakers & Participants \\
\hline 1 & $\begin{array}{l}\text { Saturday, 29-4-2017 } \\
(07.00-11.00 \mathrm{WIB})\end{array}$ & $\begin{array}{l}\text { Modul I, LCD, } \\
\text { Projector, Laptop }\end{array}$ & $\begin{array}{l}\text { - Introducing Swishmax } \\
\text { - Installation }\end{array}$ & Nanda & 16 people \\
\hline 2 & $\begin{array}{l}\text { Friday, 5-5-2017 } \\
\text { (07.00-11.00 WIB) }\end{array}$ & $\begin{array}{l}\text { Modul II, Modul III, } \\
\text { LCD, Projector, } \\
\text { Laptop }\end{array}$ & $\begin{array}{l}\text { - Text Animation } \\
\text { - Motion Animation }\end{array}$ & Vido, Yeni & 14 people \\
\hline 3 & $\begin{array}{l}\text { Saturday, 6-5-2017 } \\
(07.00-11.00 \mathrm{WIB})\end{array}$ & $\begin{array}{l}\text { Modul III, Modul } \\
\text { IV, Modul V, LCD, } \\
\text { Projector, Laptop }\end{array}$ & $\begin{array}{l}\text { - Image Animation } \\
\text { - Audio Effects } \\
\text { - Button }\end{array}$ & Vido, Yeni & 14 people \\
\hline 4 & $\begin{array}{l}\text { Friday, } 12-5-2017 \\
(07.00-09.00 \mathrm{WIB})\end{array}$ & $\begin{array}{l}\text { Modul V, LCD, } \\
\text { Projector, Laptop }\end{array}$ & - Button and Script & Vido, Yeni & 14 people \\
\hline
\end{tabular}

Table 2

Workshop Technique

\begin{tabular}{cllccc}
\hline No & \multicolumn{1}{c}{ Day, Date } & \multicolumn{1}{c}{ Tools } & Materials & Speakers & Participants \\
\hline 1 & Friday, 12-5-2017 & Modul I-V, LCD, & Creating learning media & Vido, Yeni & 14 people \\
& $(09.00-11.00$ WIB $)$ & Projector, Laptop & & & \\
\hline 2 & $\begin{array}{l}\text { Saturday, 13-5-2017 } \\
(07.00-11.00 \text { WIB })\end{array}$ & $\begin{array}{l}\text { Modul I-V, LCD, } \\
\text { Projector, Laptop }\end{array}$ & Creating learning media & Nanda & 14 people \\
\hline
\end{tabular}

2. Workshop Technique

Workshop is used by the participants to apply their knowledge during training. I this stage, each participant create a product in the form of learning media according to their own ideas. One example of the products is slide presentations. The slide presentations are various ranging from two-dimensional figures, animals' metamorphoses, plant breeding, etc. This workshop is done in 2 meetings with the following schedule (Table 2). Tutors' training is attended by 16 participants who are the representatives of 8 clusters. In its implementation, 14 out of 16 actively join with their $100 \%$ present. This 14 people will be peer tutors in dissemination.

\section{B. Dissemination}

Dissemination is done in two meetings. This stage aims at sharing with colleagues. Speakers in this stage are those who have been prepared in the previous stage. 14 out of 16 people who actively join the initial training become tutor in this stage. Two methods I this stage are conducted at one time. Those two methods are as follows:

1. Training Technique

Training is done altogether with science and technology coaching. Similar to preparing tutor training, training in this dissemination is used to transfer basic knowledge about how to operate Swishmax. The difference is that the speakers are those who have been attended previous training. Those come from each primary school in every cluster. Each cluster is required to send 2 teachers as the representatives for the low and high class. It is targeted that the participants are more or less 90 teachers from 45 available schools. However, registered participants are only 75 people, and those who attend are 72 people. Participants are divided into two classes to make it more efficient. One class consists of teachers of 1 st -5 th grade, and the rest are on the other class. These participants are guided by 4 out of 14 available tutors.

\section{Science and Technology Coaching}

Science and Technology coaching is used by the tutors and teams' members to accompany the coaching process led by 4 tutors, and guide directly the participants who need help or find difficulties in following the speakers' instructions. 14 tutors are divided into two classes; each class has 7 tutors. Also, teams' members are divided into two classes as facilitators. Two tutors are as speakers and the rest and 2 other tutors are as facilitators.

Table 3

Dissemination Schedule of Class A (Cluster I-V)

\begin{tabular}{clllll}
\hline No & \multicolumn{1}{c}{ Day, Date } & \multicolumn{1}{c}{ Tools } & \multicolumn{1}{c}{ Materials } & \multicolumn{1}{c}{ Speakers } & Participants \\
\hline 1 & Tuesday, 30-5-2017 & Modul I-V, LCD, & - Introducing Swishmax & Mr. Makin & 72 people \\
& $(07.30-11.00$ WIB $)$ & Projector, Laptop & - Installation & Ms. Mutini & \\
& & & - Text Animation & PIC: Vido & \\
\hline 2 & Wednesday, 31-5-2017 & Modul I-V, LCD, & - Image Animation & Mr. Makin & 72 people \\
& $(07.30-11.00$ WIB $)$ & Projector, Laptop & - Audio Effect & Ms. Mutini & \\
& & & - Button & PIC: Nanda & \\
& & & - Script & & \\
\hline
\end{tabular}


Table 4

Dissemination Schedule of Class B (Cluster VI-VIII)

\begin{tabular}{|c|c|c|c|c|c|}
\hline No & Day, Date & Tools & Materials & Speakers & Participants \\
\hline 1 & $\begin{array}{l}\text { Tuesday, 30-5-2017 } \\
(07.30-11.00 \mathrm{WIB})\end{array}$ & $\begin{array}{l}\text { Modul I-V, LCD, } \\
\text { Projector, Laptop }\end{array}$ & $\begin{array}{l}\text { - Introducing Swishmax } \\
\text { - Installation } \\
\text { - Text Animation } \\
\text { - Motion } \\
\text { - Image Animation } \\
\text { - Audio Effects }\end{array}$ & $\begin{array}{l}\text { Mr. Heri } \\
\text { Ms. Husna } \\
\text { PIC: Yeni }\end{array}$ & 72 people \\
\hline 2 & $\begin{array}{l}\text { Wednesday, 31-5-2017 } \\
(07.30-11.00 \text { WIB })\end{array}$ & $\begin{array}{l}\text { Modul I-V, LCD, } \\
\text { Projector, Laptop }\end{array}$ & $\begin{array}{l}\text { - Button } \\
\text { - Script }\end{array}$ & $\begin{array}{l}\text { Mr. Heri } \\
\text { Ms. Husna } \\
\text { PIC: Vido }\end{array}$ & 72 people \\
\hline
\end{tabular}

Table 5

Dissemination Schedule of Class A (Cluster I-V)

\begin{tabular}{cllll}
\hline No & \multicolumn{1}{c}{ Day, Date } & \multicolumn{1}{c}{ Speakers } & \multicolumn{1}{c}{ Facilitators } & Participants \\
\hline 1 & Tuesday, 30-5-2017 & Mr. Makin & Mr. Im Safi'i & 72 people \\
& $(07.30-11.00$ WIB) & Ms. Mutini & Ms. Elin & \\
& & Ms. Binti & \\
& & PIC: Vido & Ms. Ririn & \\
& & & Ms. Diyan & 72 people \\
& & & Ms. Sunarsih & \\
& & & Mr. Im Safi'i & \\
& Wednesday, 31-5-2017 & Mr. Makin & Ms. Elin & \\
& & Ms. Mutini & Ms. Binti & \\
& & & Ms. Ririn & \\
& & & Ms. Diyan & \\
& & & Ms. Sunarsih & \\
\hline
\end{tabular}

Table 6

Dissemination Schedule of Class B (Cluster VI-VIII)

\begin{tabular}{cllll}
\hline \multirow{2}{*}{ No } & \multicolumn{1}{c}{ Day, Date } & \multicolumn{1}{c}{ Speakers } & \multicolumn{1}{c}{ Facilitators } & Participants \\
\hline 1 & Tuesday, 30-5-2017 & Mr. Heri & Ms. Nurul \\
& Ms. Tina \\
& $(07.30-11.00$ WIB $)$ & Ms. Husna & Ms. Ida & 72 people \\
& & PIC: Yeni & Ms. Tiyas & \\
\hline 2 & Wednesday, 31-5-2017 & Mr. Heri & Ms. Nurul & people \\
& $(07.30-11.00$ WIB $)$ & Ms. Husna & Ms. Tina & \\
& & Ps. Ida & Ms. Tiyas & \\
\hline
\end{tabular}

\section{RESUltS}

Swishmax training gives positive impacts for elementary schools teachers in Ngunut sub-district. This can be known from the given questionnaire in initial training. All tutors-to-be who has attended training participants think that all applications in laptop are only Microsoft Office: Words, Excel and PowerPoint. After joining the training, teachers who firstly not know about the application, especially Swishmax, now know and are able to operate this application. Participants' improvement of knowledge and skills of Swishmax are recorded in pre-test and post-test presenting as follows.

Through Swishmax, teachers can produce a product that is interesting learning media. From this result, it is known that teachers' skills in utilizing technology as means to support learning process have been improved. By this improvement, it means that the professional competences of teachers also improve. However, resulted learning media is only limited to slide presentations. This is because limited time compared to numerous materials of Swishmax should be mastered. Studied materials are Tools Box (Text,
Shape, Motion Path) to create texts and objects, and move the objects; Effects (giving effects to the objects), Insert Files (inserting files); Button (making buttons); Script (Frame and Movie Control), that is giving command to the objects. Meanwhile, Script is need to master deeper.

\section{A. Potential Results}

From this training, several potential results can be developed in the future time. First, teachers who have the knowledge and skills of operating Swishmax can independently develop their skills to create interesting learning media and make abstract theory to be more real. Second, resulted learning media can be distributed and utilized by other teachers who have known Swishmax yet. Third, teachers can share their knowledge to other teachers and ask them to create their own. Fourth, having this skill, teachers can develop their skill by joining other trainings or learn independently until they master all the operations on Swishmax hoping that they can create an interesting educational game. In addition, this training is expected to be able to activate KKG activities. 


\section{B. Next Stage Planning}

Swishmax training to improve primary schools teachers' professional competences in Ngunut subdistrict, Tlungagung has been fully implemented. Next stage planning is to complete the materials by giving training on related materials deeper. The material is about Script. Script has a very large covering. From 20 main points of Scripts menu, only 2 of them that have been delivered: Frame and Movie Control. These 2 menus are the main instructions which have to be mastered by beginners; further instructions can be learned if the individuals want to master Swishmax deeper.

\section{REFERENCES}

[1] Data Sekolah Dasar di Kecamatan Ngunut, Tulungagung. Retrieved June 5, 2017, http://referensi.data.kemendikbud.go.id/.

[2] 2017 , . Ngunut, Tulungagung. Retrieved June 23, http://id.m.wikipedia.orgwiki/Ngunut._Tulungagung.

[3] Elka, N. D. 2017. Materi TIK. Retrieved June 5, 2017, http://teknologielka.blogspot.co.id/p/materi-tik.html).

[4] Kurnia, A. 2012. Pengertian Swishmax. Retrieved June 15 , 2017 ,

http://adamerc.blogspot.co.id/2012/11/pengertianSwishmax.html.

[5] Rosyid, A. 2015. Fungsi Kelompok Kerja Guru (KKG) bagi Pengembangan Keprofesionalan Guru di Sekolah Dasar. Retrieved June 13, 2017, http://idr.iainantasari.ac.id. 